\title{
Which Place for the Homeless in Delhi? Scrutiny of a Mobilisation Campaign in the 2010 Commonwealth Games Context
}

\section{Véronique Dupont}

\section{(2) OpenEdition \\ Journals}

Electronic version

URL: http://journals.openedition.org/samaj/3662

DOI: 10.4000/samaj.3662

ISSN: 1960-6060

Publisher

Association pour la recherche sur l'Asie du Sud (ARAS)

\section{Electronic reference}

Véronique Dupont, "Which Place for the Homeless in Delhi? Scrutiny of a Mobilisation Campaign in the 2010 Commonwealth Games Context», South Asia Multidisciplinary Academic Journal [Online] 8 | 2013, Online since 19 December 2013, connection on 19 April 2019. URL : http:// journals.openedition.org/samaj/3662 ; DOI : 10.4000/samaj.3662

This text was automatically generated on 19 April 2019.

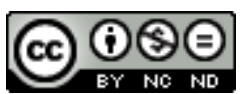

This work is licensed under a Creative Commons Attribution-NonCommercial-NoDerivatives 4.0 International License. 


\title{
Which Place for the Homeless in Delhi? Scrutiny of a Mobilisation Campaign in the 2010 Commonwealth Games Context
}

\author{
Véronique Dupont
}

1 On 25 December 2009, ${ }^{1}$ a leading Delhi newspaper published on its front page a photo of people shivering in the cold, while the Municipal Corporation of Delhi (MCD) destroyed their temporary night shelter to 'beautify' the place for the 2010 Commonwealth Games. ${ }^{2}$ These people, previously living in a nearby slum cluster, had been made homeless in 2000 after their settlement was demolished to construct an elevated metro line and they had been excluded from the resettlement scheme for displaced slum dwellers. Their brutal eviction triggered a mobilisation campaign for homeless people's rights. This story exemplifies the effects of Delhi's transformation, the aim of which is to create 'a global metropolis and a world-class city' (DDA 2007: Introduction) at the cost of large-scale slum demolitions. The construction of the metro railway-a flagship infrastructure projectand the preparations for the 2010 Commonwealth Games, are emblematic of the sociospatial restructuring and makeover that have changed Delhi and affected those living on its margins over the last dozen years.

2 Elsewhere (Dupont 2011) I explored which facts and realities on the ground formed the basis of this world-class ambition, and showed how the drive for global competitiveness and its associated image-building translated into a 'revanchist city' (Smith 1996, MacLeod 2002), treating the visible poor, especially slum dwellers and the homeless, as undesirable elements to be removed from city space. 'Crusades to clean up the city' (Davis 2006: 104) on the eve of international events is a leitmotiv for urban authorities, as witnessed in Beijing for the 2008 Olympic Games (Broudehoux 2007) or Johannesburg for the 2010 Soccer World Cup (Bénit-Gbaffou 2008). Delhi corroborated such trends before the 2010 Commonwealth Games. 
The focus here is on the struggle of and for the homeless people to assert their place in the city, and on a decisive moment: the 2010 mobilisation campaign for the homeless' rights, which was launched in the above environment. The main questions underlying this study are: which place is left for the homeless in Delhi, which place is claimed? First, I highlight the case study's significance by situating it within the broader context of homelessness in the capital. Homelessness is not a new phenomenon in Indian cities. Nevertheless, the dramatic increase of the homeless population in Delhi over the last decade and the changes in its composition require us to analyse the factors and mechanisms responsible for such developments. Second, in order to understand better the types of claims expressed during the 2010 campaign as well as the conditions of mobilisation, I examine the government's responses to the plight of the homeless and the role of civil society organisations (CSOs). This allows us to go beyond the revanchist city framework and evidence the ambivalence in homeless policies that include accommodative responses and not merely punitive measures-a complexity underlined in other contexts (DeVerteuil 2006, DeVerteuil, May et al. 2009). Third, I scrutinize the mobilisation campaign's modalities, analyse the factors and interplay of actors that led to its success, and question the sustainability of the outcomes.

4 To assess the place of the homeless in the city, I look at their spaces: the physical spaces they occupy or are made to live in after slum demolition and the 'spaces of citizenship' (Miraftab 2004) provided by the state and the spaces that they claim. This framework utilises the concept of 'space of participation' first articulated by Cornwall (2002) and refined by Miraftab (2004) who distinguishes between 'invited' and 'invented' spaces of citizen participation:

5 Invited spaces are defined as the ones occupied by those grassroots and their allied nongovernmental organisations that are legitimized by donors and government interventions. 'Invented' spaces are those, also occupied by the grassroots and claimed by their collective action, but directly confronting the authorities and the status quo (Miraftab 2004: 1).

6 This paper underlines the limitations of the 'invited spaces' for participation provided by the government to the homeless in Delhi, which resulted in other modalities of mobilisation emerging during the 2010 campaign. The use of the concept of 'invented' or 'conquered' (Cornwall \& Coelho 2007) spaces of citizenship, also termed 'spaces of insurgent citizenship' (Holston 1995, Miraftab \& Wills 2005), draws attention to the homeless citizens' agency, albeit constrained. This follows the approach promoted by the subaltern studies that recognise 'the exercise of agency by subaltern subjects', including in the context of eviction (Baviskar 2003: 97). The case study shows how the homeless emerge as 'agential beings' (see Govinda, Introduction to this volume), actors able to deploy strategies or at least tactics of resistance (DeVerteuil, Marr et al. 2009) and, with the decisive support of CSOs, to claim recognition for their contribution to the city. By starting to assert their urban rights, they challenge their relegation to the capital's margins.

7 This research combines different sources of information, including secondary data (official statistics and policy documents, court orders and related documents, NGOs' reports and press reviews) and direct field investigations. The field observations were carried out in five periods between November 2009 and April 2013. They include in-depth interviews with various stakeholders (evicted homeless, CSOs, independent activists and 
government officers) as well as attendance at public meetings, consultations for the homeless and press conferences.

\section{From houseless to homeless: the adverse effects of slum clearance policies}

In this paper, houseless and homeless refer to 'people living without basic shelter on the streets, under flyovers and bridges, in public parks and other common spaces that pose a significant threat to their privacy, health, personal security and safety' (IGSSS 2012: 25).

The exact number of homeless people in Delhi is not known. The invisibility of certain sections of this population, such as those who sleep in concealed places, makes its enumeration difficult. The main NGOs in this field estimated the homeless population in 2012 to have been around 150,000 or more (AAA-Aashray Adhikar Abhiyan website, ${ }^{3}$ IGSSS 2012). In fact, various enumerations and surveys of the homeless have been conducted in Delhi since 2000 (AAA 2001, GNCTD-UNDP 2011, Maitra \& Metha 2007, SCCO 2011, Tingal \& Kumar Pandey 2008). The variations in estimates can probably be explained by the different methodologies used. The headcounts conducted by two NGOs, one in 2000 (AAA 2001) and the second in 2008 (IGSSS 2012, Tingal \& Pandey 2008), deserve particular attention as they followed similar methodologies, thus giving comparable figures. They indicate a $68 \%$ increase in the homeless population in Delhi from 2000 to 2008, attributed for the most part to massive slum demolitions without adequate resettlement options for the evicted (IGSSS 2012).

\section{Major changes in the shelterless population of Delhi}

10 Although the homeless form a heterogeneous population that cannot be reduced to a single category of 'urban poor', various surveys have shown some common characteristics (AAA 2001, Dupont 2000, GNCTD-UNDP 2011, IGSSS 2012, Maitra \& Metha 2007). Homeless people surveyed in Delhi were predominantly male adult migrants from rural areas who had left their homes due to economic compulsions-lack of economic opportunities and poverty. Several became homeless, especially children and women, after being compelled to leave their home by familial conflicts. The homeless population forms an integral part of the metropolitan labour force. Their lack or very low level of formal education means they are mainly employed as unskilled, casual and temporary workers. A majority were saving and remitting money to their families back home, thus maintaining contact with their rural origins.

11 In my study of the 'houseless' in Old Delhi, conducted in 1996, I emphasised that the economic rationales of some individual migrants leads them to try to maximize remittances to their families by cutting housing and transport expenses and giving priority to sleeping near their workplace or labour market (Dupont 2000: 119). At the time, I deliberately used the terms 'houseless' and 'houselessness' rather than 'homeless' and 'homelessness' to indicate that the lack of physical shelter in Delhi was in most cases combined with a home and a family elsewhere, especially in the village of origin (see also IGSSS 2012, GNCTD-UNDP 2011, Maitra \& Metha 2007).

12 The large-scale slum demolitions, associated with the restructuring of Delhi to meet the ideals of its globalisation-in-the-making, have engendered an additional and significant 
section of shelterless people, victims of evictions who can be described as the true homeless. In 2008, approximately 2000 families were found living on the streets in different areas of the capital, some of them claiming they had lived in this condition for over four years, ever since the demolition of their jhuggis (hutments) (IGSSS 2012: 71). In the past, most of the homeless were lone individual men (AAA 2001, Dupont 2000). Families living on the streets are, however, only one indicator of homelessness due to eviction, as some families send their non-working members back to the village and leave the main earner alone in Delhi. Many evicted slum families who were excluded from resettlement programmes (Dupont 2010) were unable to overcome the shock of eviction and its resulting multidimensional impoverishment, leading to homelessness. Adverse effects on employment, income, education, health, familial and social life compounded the eviction's disastrous impact on shelter conditions and concomitant loss of rights and successive deprivations, thereby jeopardizing these people's right to be part of the city and to live with dignity (Dupont 2010).

slum clearance policies can lead to homelessness despite the implementation of jhuggijhompri resettlement programmes, which excluded many families for several reasons. ${ }^{4}$ First, the principle of a cut-off date of arrival in the settlement as an eligibility criterion necessarily excluded many families who found themselves on the streets without any compensation or alternative arrangement. Second, the financial contribution required from included families for a plot in a relocation site and the additional related expenses led to the exclusion of the poorest families and impoverished them even more by making them homeless. Third, dysfunctions and malpractices in the programme's implementation also resulted in the exclusion of a number of eligible families (Dupont 2010). Furthermore, these resettlement programmes did not include any re-housing. The allotment of a plot on a site located in the urban periphery, often very far from the original establishments, neither ended residential instability nor prevented homelessness. The resettlement process itself involved high costs and subsequent hardships for the relocated families (Khosla \& Jha 2005, Menon-Sen \& Bhan 2008). Many ended up-illegally-reselling their entitlements to a plot for immediate monetary gains, leading to housing insecurity and precariousness in areas close to employment sources. To secure income, squatting or homelessness in a more central area was preferred to land security in far-off peripheries. The story, examined in the last part of this paper, of a group of families evicted from a demolished slum cluster, exemplifies some of these exclusion and impoverishment mechanisms.

\section{Extent of slum demolition without resettlement}

14 According to the Delhi Urban Shelter Improvement Board (DUSIB)'s estimates, there were 685 jhuggi-jhompri clusters housing around two million people in 2011, accounting for $12 \%$ of the Delhi urban agglomeration population (that is 16 million not including peripheral towns) whereas in 1998 there were about 1100 such settlements, housing around three million people, accounting for approximately $27 \%$ of the population of the capital at the time. ${ }^{5}$ The results of the last census reveal a considerable slowing of population growth from 2001 to 2011 in the inner districts of the Territory of Delhi, including an absolute decrease in population in New Delhi District and Central District attributed to the largescale slum demolitions (Joshi 2011: 49). Part of this absolute decrease may in fact conceal gross under-counting of the homeless population during the census. Although some evicted slum dwellers that were not resettled may have returned to places of birth or 
relocated to other urban areas, it is likely that many of them, by becoming homeless, have also become 'invisible' in the official population statistics.

It remains difficult to know exactly how many evicted slum families were excluded from the resettlement programmes and how many remained homeless. Conservative estimates suggest that at least half of the total numbers of families evicted from 1990 to 2007 were not resettled (Bhan \& Shivanand 2013). Ghertner (2010: 202) calculated that from 1997 to 2007 'close to a million slum dwellers have been displaced'. These figures can be confronted with the official statistics of squatter families relocated from 1990-1991 to 2008 under the jhuggi-jhompri resettlement scheme: around 65,000 families over the entire period, accounting for about 325,000 people ${ }^{6}$, i.e. only a small fraction of the total number of displaced people. Infrastructure projects and the context of and preparations for the 2010 Commonwealth Games played a significant role in the demolition of slums located on coveted urban land (Dupont 2008). The international sporting event was preceded by a spate of 'last-minute demolitions' carried out without resettlement. A fact finding mission revealed that, in a sample of 19 sites in central areas of Delhi, of the 3000 families evicted by the government in 2009-2010 because of the Commonwealth Games, only 85 were resettled (HLRN-HIC 2011).

The extent of slum demolition without resettlement may not be a direct indicator of eviction-induced homelessness. Nonetheless, it suggests the creation of urban conditions bearing an increased risk of homelessness. While some evicted families are able to escape from land insecurity and improve their housing conditions, others remain trapped in poverty, squatting in precarious settlements or homeless (Dupont 2010).

\section{Government responses and civil society involvement: towards more invited spaces?}

17 In order to comprehend the context of homelessness in Delhi, we need to examine the government responses to the plight of the homeless. In this second part, I focus mainly on the situation prior to the launch of the mobilisation campaign, specifically on the invited spaces for participation which the government provided to CSOs. This allows us to better understand the developments analysed in the third part of the paper, especially the demands expressed during the campaign for the right to shelter of the homeless and the emergence of modalities of mobilisation outside these invited spaces.

In Delhi, interactions between the voluntary sector and the government were noticeable since the inception of the first night shelter for the homeless in the 1960s, owing to the advocacy of the organisation Bharat Sevak Samaj (1964). These interactions acquired a momentum with the formation of Aashray Adhikar Abhiyan (AAA) in 2000, an NGO dedicated to the 'Shelter rights campaign for the homeless in Delhi' (supported by Action Aid India, affiliated to Action Aid International). Following this initiative and with active linkages built by AAA to other NGOs, religious groups, human rights movements and the government, several organisations became involved in the issue of homelessness (IGSSS 2012: 62-64). The latter ranged from local associations, including a community-based organisation ( $\mathrm{CBO}$ ) of homeless people, to national organisations receiving external funding, as well as branches of international organisations. These initiatives marked a new trend in governance: the increasing involvement of CSOs in government schemes for the homeless. 
19 Although the National Capital Territory of Delhi became, in 1991, a quasi-state with its own government and Assembly, the central government retained control over land, police, law and order. Thus, the Delhi Development Authority (DDA)-the agency responsible for preparing the Master Plans for Delhi and monitoring the planned development of the capital city-is under the purview of the central government. At the third tier, the MCD and its Slum Department played an important role in squatters' resettlement programmes (as we have seen) and in schemes for the homeless. These multiple authorities and overlapping jurisdictions entailed diffused accountability as well as coordination issues, as the case study will illustrate.

\section{Night shelter schemes for the homeless}

The first government programme of night shelters for the homeless was initiated under the Seventh Five-year Plan (1985-1990). It was operated, from 1991 to 2010, by the Slum Department under the MCD; it is now part of the DUSIB under the Government of Delhi. The scheme consists of operating shelters located in areas of homeless concentrations, providing facilities for night stay (including toilets, blankets and jute mats) at nominal charges. In December 2009, before the mobilisation campaign for the homeless, there were only 12 night shelters in buildings run by the MCD, and none were for women. In addition, there has been a scheme of temporary shelters in the winter, implemented by the Delhi Government's Revenue Department. After being discontinued in 1994, the scheme was revised and resumed in 2002 following pressure from AAA on the government. The revised scheme involves NGOs as partners: the government provides tents for emergency relief to protect homeless people from the cold weather and NGOs manage these temporary night shelters. In the 2000s, 25 tents were put up in the winter in various locations. However, on the eve of the mobilisation campaign, the total capacity of sleeping places provided under these schemes was grossly inadequate in terms of meeting the homeless population's needs.

21 A Joint Apex Advisory Committee for the Homeless and Street Children was constituted in 2002 under the Additional Commissioner of the Slum Department, with members from the Delhi Police, the Delhi Government and CSOs (IGSSS 2012: 63). Weekly discussion meetings were followed by decisions and implementation. The CSOs appreciated this 'invited space' for participation, which was even projected as a model of GovernmentNGO partnership ${ }^{7}$ and played a major role in the setting up of temporary night shelters in the winter. However, the Committee became inactive following the transfer in 2004 of one of its most active members among the government officers. This exposes the fragility of structures dependent on asymmetric power relations between the 'hosts' (here local urban bodies) and the 'invited' participants (CSOs).

A notable demand made by the CSOs for the homeless was pushed forward under a platform called Sajha Manch, during consultations organised by the DDA over a draft version of the 2021 Master Plan. ${ }^{8}$ As a result, in a departure from the previous Plans, the 2021 Master Plan for Delhi (notified in 2007) stipulated a ratio of one night shelter for a population of 100,000 (DDA 2007: section 4.3). This is of particular importance as the Master Plan is a mandatory document, approved by the Union Ministry of Urban Development, and this proviso was used in the campaign for the right to shelter for the homeless. 


\section{Public-Community partnership under Mission Convergence: a new paradigm?} comprehensive survey of the homeless in order to better understand their demographic and socio-economic profile and to plan adequate delivery of services (GNCTD-UNDP 2011). The survey was also conceived as a tool to provide identity cards to the homeless and to link this exercise with enrolment in the National Population Register and the Unique Identification (UID) number project. ${ }^{11}$ The biometric identification implied by this operation has faced practical difficulties and controversies. The consensus among CSOs and the homeless is that the lack of legal identity and residence proof is a priority issue, as this bars the homeless from accessing fair price shops, pensions and other similar schemes, and, more significantly, prevents the exercise of their voting rights. However, the enrolment of the homeless in the UID project raised a series of criticisms, which led one prominent NGO, initially part of the process, to withdraw from it. ${ }^{12}$ Nonetheless, this experience revealed limitations in the public-community partnership model promoted by Mission Convergence, and its implications for the larger civil society movement for the homeless, which I will discuss later.

In the 2000s, therefore, several organisations were already active in the field of homelessness. They contributed to some positive outcomes, such as resuming the scheme for winter temporary shelters, and the stipulation of a ratio for night shelters in the Master Plan for Delhi. This was achieved through invited spaces for participation. However, as shown in the third part of this paper, the 2010 campaign for the right to shelter for the homeless highlighted the inadequacy of the services provided under the public schemes. The campaign analysis also reveals the limitations of the government's invited spaces, accounting for the CSOs resorting to other mobilisation spaces. 


\section{An emblematic case: the story of Rajendar Nagar slum cluster}

Slum clearance for the capital city's redevelopment and beautification, without adequate rehabilitation, often resulted in pushing unwanted settlements further into marginal physical and economic spaces, or in throwing their dwellers into the streets without solving the issues of suitable shelter for the poor. This is illustrated by the case of people rendered homeless from Rajendar Nagar slum. The last eviction that affected this group of families triggered a mobilisation campaign for the homeless, which is examined here. The questions underlying the case study are: what factors and interplay of actors might explain this campaign's success? What kinds of spaces were mobilised for participation and contestation? What are the main challenges facing the sustainability of the campaign outcomes?

\section{Overview of case story: chronology of main events}

Most of the families who lived in the Rajendar Nagar slum cluster-and now temporarily resettled in the Motia Khan municipal night shelter, about 350 people-hail from northern Karnataka. They are mainly Vadaru (a Scheduled Caste which traditionally specialised in stone breaking) and are illiterate. Chased by poverty and food scarcity, many arrived in Delhi about 30 years ago and worked as stonebreakers on construction sites, as peddlers, or as rickshaw pullers. Living on the pavement and moving from one place to the other according to work opportunities was quite common for them. In 1982, they finally set up their jhuggis in Rajendar Nagar, in an unclaimed vacant plot where human bones had been found, as advised by a local politician. The construction of a metro line in 2000 disrupted the life of this community and their efforts to build a place for themselves in the city. This first eviction deprived the slum dwellers of the resettlement plot they were entitled to, and rendered them homeless: they were unable to pay the required fees, they relied on unscrupulous agents to whom they gave their original proofs of identity and residence (especially their ration cards), they lacked unity, organisation and mobilisation, were manipulated and were victims of fraudulent practices by a nexus of property dealers, corrupt municipal officers and often violent police.

Rendered houseless and impoverished by their losses consequent upon eviction, the families from Rajendar Nagar slum resumed their life of urban nomads, moving from one place to the other according to job opportunities, chased from one street corner to the other by the police. A group of families established a precarious camp on a roundabout open space on Pusa Road, close to their former settlement. They were violently expelled by the police in June 2009, but were back in winter, sheltering in tents temporarily put up by the Delhi government. The MCD ignored this public relief scheme and on 22 December 2009 a municipal squad destroyed the tents, forcibly evicted the people and seized all their belongings. The reason stated for the demolition was to grow grass on the roundabout as part of the beautification drive for the October 2010 Commonwealth Games, though the roundabout was far from any of the Games' venues. There were dramatic consequences of this demolition: two homeless people died from the cold. In this last eviction, an international event was a pretext for the beautification of the capital's landscape as well as for its 'social beautification' (Broudehoux, 2007: 390). ${ }^{13}$ Also 
evident was the complete lack of coordination between the state government that put up the temporary shelters and the MCD that destroyed one of those shelters a few weeks later.

The eviction of homeless people in the winter and the ensuing deaths from the cold triggered a protest movement and the suo moto intervention of the judiciary in January $2010 .{ }^{14}$ The High Court of Delhi then ordered the MCD to provide the evicted families with temporary shelter until a permanent solution was found. The affected homeless families were resettled in a municipal building-the Motia Khan night shelter-where they were still staying in November 2013, supported by NGOs and charitable organisations. The analysis of the sequence of events in the mobilisation campaign illustrates the respective roles of the different actors in the movement and highlights the interactions between the various actors involved in urban governance: the state government and the MCD; CSOs, including human right movements, NGOs and grassroots organisations working with the homeless; the High Court of Delhi and the Supreme Court of India; the media. These interactions are examined in the next section.

\section{A successful mobilisation and scaling-up campaign}

\section{Campaign outcomes}

31 This successful mobilisation and scaling-up campaign transcended the demolition of one temporary night shelter and addressed the larger issues of evictions, lack of adequate shelter, right to life and food for homeless people dying on the streets, and had additional outcomes besides the resettlement of the evicted homeless families. Several night shelters for homeless people were opened in Delhi following the advocacy by housing rights organisations and other CSOs, and the directions of the High Court of Delhi ${ }^{15}$ and of the Supreme Court ${ }^{16}$ in January 2010. The Master Plan for Delhi 2021, with its provision for the homeless, was used as a reference. Around 90 new night shelters were opened in Delhi in less than a month: 52 in government buildings and the rest in temporary structures. More were opened later. As a result, the number of night shelters in Delhi was unprecedented and unparalleled compared to other Indian cities. The issue of lack of shelter for the homeless was brought to the Supreme Court of India under an ongoing Public Interest Litigation (PIL) on the right to food, ${ }^{17}$ and broadened to all major cities of the country. The Supreme Court asked each state to submit a report on the situation of the homeless and the night shelters in their cities with a population above 500,000, with the view that night shelters should be provided in the ratio of at least one per 100,000 population. ${ }^{18}$ The scope of shelters for the homeless was also broadened following the Courts' instructions on the basis of reports submitted by CSOs: from providing night shelters in winter, to 24 -hour shelters with adequate facilities, running all year round.

Furthermore, the recommendations of the working group on urban poverty at the National Advisory Council (a government think-tank under the Prime Minister's Office) for a national programme for shelters and other services for the urban homeless ${ }^{19}$ were an indirect outcome of the campaign in March 2012. Their proceedings were not unrelated to the announcement by the President of India, in her address to Parliament on 12 March 2012, of a new scheme, the National Programme for the Urban Homeless. In this context, the Housing and Urban Development Corporation launched, for its 2012 trophy, a competition for architecture students to design shelters for the homeless. ${ }^{20}$ 
33 At the grassroots level, the mobilisation of the CSOs for the Pusa Road eviction case exceeded its initial focus. The success of this specific campaign boosted the larger movement for the homeless. A 'National City Makers Caravan'-an original 'invented' space-was organized to take up on a national level the various issues of urban homelessness. The caravan aimed to sensitise government authorities, the media, and the general public to those concerns. It collected data about the conditions of homeless people in various states, including, with respect to the directive of the Supreme Court, the provision of night shelters. This caravan covered 22 states across India, from August 2010 to January 2011, spreading awareness of homeless people's rights and creating a network of concerned CSOs. ${ }^{21}$ This initiative was led by a national NGO working with marginalised and vulnerable sections of the society, including homeless people; it was supported by two big organisations, members of international confederations (Caritas India and Oxfam India), and was conducted in collaboration with around 40 various CSOs from across the country. Homeless people contributed significantly: around 1,500 of them from Delhi followed the Caravan and were joined in each city by other groups, they conducted a signature campaign among themselves, took part in a series of rallies, and performed street plays on their day-to-day problems. At the same time, a very significant semantic change marked the campaign for the urban homeless: from 'homeless people'a descriptive term-to 'homeless citizens', with an underlying stress on rights and entitlements, and finally to 'city makers'-a term which asserts their 'significant constructive role in a city's development', as 'the real builders of the city'. ${ }^{22}$ The last term reflects 'a shift from entitlement citizenship to activism citizenship' ${ }^{23}$ in the mobilisation for the homeless. In other words, the recognition that formal entitlements do not guarantee substantive rights in the city (Zérah et al. 2011) encouraged practices of 'active citizenship' (Miraftab \& Wills 2005), namely 'insurgent practices [that] move across the invited and the invented spaces of citizenship' (Holston 1995: 35). The organisation of rallies, informal public hearings and consultations ${ }^{24}$ on homelessness-related issues further contributed to giving a voice to these marginalized people now claiming a proper place in the city, and in restoring their dignity, too often outraged by harsh living conditions. In such public meetings, homeless people, men as well as women, could speak to share their experience and articulate their demands on the same platform and on par with speakers from very different social classes, status and professional categories. The outcomes of this larger campaign can be definitely considered an achievement in terms of increased visibility and empowerment of the urban homeless. These various initiatives indicate the emergence of the homeless as agential beings. A last major success of the movement in this regard is the enrolment of homeless persons in voter lists, thanks to the unrelenting demands and support of NGOs. Although the distribution of voter cards, initiated in late 2012, is still limited, ${ }^{25}$ the right conferred-or rather reinstated-to the homeless is undoubtedly a crucial step in enhancing their agency as citizens.

\section{Factors for success}

The conjunction of several factors explains the success and scaling-up of this mobilisation campaign. Various CSOs, including NGOs (local organisations as well as national ones supported by international donors), ${ }^{26}$ human rights movements, ${ }^{27}$ a grassroots organisation of homeless people, and individual activists who had been working in the field of homelessness for more than ten years, combined their respective strengths and fields of expertise within a coalition, Shaheri Adhikar Manch: Begharon Ke Liye ${ }^{28}$ (SAM-BKL) 
-the Urban Rights Forum for the Homeless, formed in September 2008, now consisting of more than 30 organisations and activists. The previous years of work for and with the homeless, as well as the efforts in coordinating various initiatives, had prepared the ground for an efficient and quick mobilisation. The homeless people themselves took an active part in the movement: some-actual or former homeless-as activists in the CBO which is a core member of the coalition, and many others as participants in the public meetings and rallies organised by their grassroots organisation or other NGOs. The efficacy of the coalition rests, in addition to its communication skills, on its vertical linkages from the grassroots level to the higher level of the bureaucracy and the judiciary.

This coalition had already established good contacts with the media as a strategy to sensitise the public to the homeless' condition and to highlight the coalition's initiatives. Thus, the media were promptly alerted and they subsequently publicised the case and raised the issues. The coalition denounced, in a press conference on 4 January 2010, the inadequacy of the number of night shelters and the non-compliance with the norms stipulated in the Delhi Master Plan, as well as the lack of a comprehensive government policy addressing the root cause of homelessness. It condemned the destruction of the shelter despite bitter cold conditions-and with fatal consequences-and more generally the human rights violations of the homeless. This press conference played a key role in spreading the news through the media, and after reading reports in the newspapers, a High Court judge issued the suo moto notice to the MCD. Subsequent press conferences organised by the coalition and regular press releases further sensitised the media and the general public.

Additionally, some coalition members had good contacts with the judiciary, which promptly took action to protect the homeless and then monitored the implementation of its orders through regular hearings. A coalition member, former special rapporteur on adequate housing at the United Nations Human Rights Council, sent a long letter to the judge who initiated the suo moto case to alert him to the context of the eviction of homeless people, the lack of adequate shelter, and the lack of respect by the Indian government for its international commitments to human rights. ${ }^{29}$

Another member of the coalition, who was special commissioner of the Supreme Court in the PIL on the Right to Food, brought the matter to the attention of the Supreme Court of India. In their report to the apex court, the commissioners evidenced the connection between people's lack of shelter and the threat to their fundamental right to life: malnutrition and hunger were listed as 'the underlying causes making people susceptible to extreme weather conditions' ${ }^{30}$ This first report ended with a series of proposals to 'ensure state accountability for the food and shelter rights of homeless people in the state of Delhi' ${ }^{31}$ This initiative led the Supreme Court to order the Government of Delhi and Municipal authorities to provide shelters to homeless people in the capital, ${ }^{32}$ and later on to give similar directives to India's other states and major cities. ${ }^{33}$ The two commissioners who alerted the Supreme Court were members of the working group on urban poverty at the National Advisory Council. This allowed the campaign to scale up further. The Delhi High Court's and the Supreme Court's interventions were decisive. Mobilisation by CSOs would not have translated so quickly into actions by the concerned government departments without the support of the judiciary. Both courts continued to monitor their orders regarding the provision of adequate shelters to homeless people. 

information (including reports with action plan and recommendations for Delhi's homeless $)^{34}$ to the High Court of Delhi for its suo moto case, which continues at the date of writing. They used the space provided by the regular hearings of the Court to highlight a range of issues related to the condition of the homeless. Not restricted to the Pusa Road shelter demolition case, they included other cases of evictions, poor maintenance and lack of proper facilities at night shelters', and police brutalities..$^{35}$ Thus, the CSOs have maintained the pressure on the concerned government departments through the Courts, preferring this 'pleading' space to express themselves and promote the cause of the homeless. In contrast, the invited spaces for participation provided by the government proved to be no longer very effective (such as the Joint Apex Advisory Committee for the Homeless-JAAC) or to be controversial (the public-community partnership under Mission Convergence). Significantly, on the court's advice, the JAAC was revived at the end of 2011 after several years of inactivity. However, it seems to lack efficiency in its present functioning. ${ }^{36}$ The courts of justice have clearly asserted themselves as inescapable and compelling actors in the governance of homelessness-related issues, directing the executive wing (the Delhi Government along with its departments and boards) to proceed as per their orders.

the success of this campaign in attaining tangible achievements for the homeless ensues from the combination of long-term structural work at the grassroots level and the timely reaction and mobilisation of various connected actors in different spheres (civil society, media, justice) and at different institutional levels (High Court of Delhi, Supreme Court, National Advisory Committee). These achievements are significant in the context of Delhi, generally fingered for its weak social mobilisation, especially with regard to slum-related issues (Bautès et al. 2013, Kumar 2008).

\section{Main challenges: sustainability of the campaign outcomes}

40 The sustainability of the campaign outcomes faces several challenges: living conditions of the resettled families, implementation of the schemes for the homeless at the city level, differing judicial views and practices, risk of media misrepresentation, and divergences in the coalition. Creating a dependency on voluntary organisations' assistance does not provide a sustainable solution as demonstrated by the living conditions of the evicted families resettled in the Motia Khan municipal shelter. Emergency and humanitarian measures cannot be substitutes for a proper rehabilitation policy that transcends the sole issue of shelter and includes measures addressing not only housing needs but also issues such as access to basic amenities, fair price shops, health care, education, vocational training and, most importantly, livelihood opportunities.

\section{Questioning the commitment of certain public agencies}

Recent developments question the sustainability of the government schemes and the commitment of the departments implementing the night shelter scheme in Delhi. During winter 2010-2011, following court orders, 148 night shelters were functioning. Of these, 64 were permanent and 84 temporary, with a total capacity of 12,500 people, compared to a total homeless population estimated at around 150,000. By December 2011, and despite previous court orders to run the shelters all year round, the DUSIB had closed 21 of its permanent shelters and most of the temporary ones, arguing that there was a lack of

South Asia Multidisciplinary Academic Journal, 8 | 2013 
attendance-a situation possibly explained by the inappropriate location and poor conditions in the shelters, especially the lack of adequate amenities and proper hygiene. Once again, the High Court of Delhi intervened and directed the DUSIB to immediately reopen all the shelters. There were other issues: the DUSIB had inducted the services of NGOs for operating and maintaining the temporary night shelters, but the NGOs did not receive their funds for several months in 2011, resulting in the closure of shelters. Some of the NGOs co-opted to run the night shelters lacked experience in this field. This underlines the limitation of voluntary organisations' participation in government schemes; as observed in the field of slum rehabilitation and resettlement (Dewan Verma 2002), NGOs can lack the strengths and skills needed to endorse the increased responsibilities transferred to them by the government, and smaller organisations are destabilised when the release of public funds is delayed (a recurrent problem).

Some incidents, such as the DDA and Indian Railways demolishing or obstructing the construction of temporary night shelters, raise further concerns. They highlight the lack of coordination among government agencies, compounded in the case of the capital city by the multiplicity of authorities, in this case at the expense of the homeless. The flaws in the Delhi 2011 homeless census also question the government's commitment to tackle homelessness issues. The NGOs assisting the enumerators exposed the shortcomings of the process and denounced blatant omissions and errors in a press conference and release: 'Census of homeless citizens in Delhi-a farce; final numbers [not released to date] will not be accepted' ${ }^{37}$ Activists rightly expressed their concern that the grossly under-estimated figures of the homeless would affect shelter planning as well as longterm housing policies, and considered it 'a case of wilful neglect by the authorities'. ${ }^{38}$ In May 2012, the DDA recommended amending clause 4.3 of the Master Plan for Delhi 2021 with regard to the ratio of shelters for the homeless reported to the total population, from one shelter per 100,000 people to one shelter per 500,000 people..$^{39}$ If adopted, this amendment would have reduced the stipulated number of shelters from 150 to just 30 . The CSOs' coalition denounced this regressive step and pressured the concerned institutions with letters highlighting the negative consequences for homeless people. Eventually, faced with the NGOs' opposition, the DDA dropped the proposal. ${ }^{40}$ This and previous episodes show that the struggle to defend the rights of the homeless requires continuous endeavours.

\section{Differing judicial views and practices}

The High Court of Delhi and the Supreme Court have monitored the provision of shelters for the homeless and other related issues. However, a thorough reading of the High Court of Delhi's interim orders evidences dysfunction, slackness and disregard of state government and civic bodies, especially in the provision of adequate amenities to the shelters, persistent lack of coordination among different public agencies, and police brutality. ${ }^{41}$

The judicial system is not always supportive of the homeless, as demonstrated in particular in the 1959 Bombay Prevention of Begging Act, extended in 1960 to the Territory of Delhi, making begging, hawking, and peddling in public places offences punishable by imprisonment or fine. It has led to the arrest and detention of homeless people, including children, in 'Beggar Homes'42 that are more jails than hostels or rehabilitation centres. The application of this law was reinforced during the preparations 
for the 2010 Commonwealth Games, and facilitated by setting up mobile courts with the aim of 'clearing' the city from ostensible poverty sights before the international event (Ramanathan 2008). Many homeless people were arrested and either detained or deported outside the capital, by a special police squad acting on the recommendation of a report commissioned by the Delhi Government's Department of Social Welfare to round up 'vagrants found begging and also potential ones' (Tandon 2007: 46). This clear denial of homeless people's right to access the city was denounced by national as well as international NGOs and human rights organisations (Amnesty International 201043; Hazards Centre 2010; HLRN-HIC 2010). To date, their demand for the repeal of antibeggary laws has been unsuccessful. Thus, in Delhi, while one branch of the judiciary was taking unprecedented measures to protect the homeless' right to shelter, another branch was curtailing their right to the city.

A rather hostile statement to the homeless is found in a Supreme Court judgement (dated 23 February 2012) on the Ramlila Maidan incident of June 2011-when followers of spiritual leader Baba Ram Dev were woken and chased at night by the police after an anticorruption rally. This judgement included a long development on the right to sleep, and on sleep as a fundamental and basic life requirement: ${ }^{44}$

An individual is entitled to sleep as comfortably and as freely as he breathes. Sleep is essential for a human being to maintain the delicate balance of health necessary for its very existence and survival. Sleep is, therefore, a fundamental and basic requirement without which the existence of life itself would be in peril. To disturb sleep, therefore, would amount to torture, which is now accepted as a violation of human right (\$38).

However, a previous paragraph of the judgement specifically excludes the homeless from the right to sleep and from the entitlement of not being disturbed during sleep:

... I am definitely not dealing herein with the rights of homeless persons who may claim right to sleep on footpath or public premises but restrict the case only to the extent as under that circumstances a sleeping person may be disturbed (\$27).

This discriminatory observation against the homeless was exposed in Delhi during a national consultation on the issue of homelessness organized by an NGO of the coalition. ${ }^{45}$ The assembly denounced the restriction in the judgment as amounting to disentitling homeless people from a fundamental right, thus not considering them equal to other citizens. Differing judicial views regarding the homeless suggest that, in addition to the context of special events, the judges' personal inclinations influence the progress-or regression-of the campaign for the rights of the homeless.

\section{Risk of misrepresentation in media reports}

The media's reports, notwithstanding their decisive role in the mobilisation campaign for the homeless in its initial stage, sometimes distort the facts and misrepresent the action of CSOs. For instance, in July 2011, several articles denounced the dismal conditions in temporary shelters for the homeless in Delhi, attributed to the 'poor NGO upkeep' ${ }^{46}$ The coalition for the homeless clarified that, while the provision of essential services was faulty in temporary shelters, the NGOs were not responsible for this situation, which was 'the result of the chronic failure of the Delhi government to comply with Court orders and provide adequate services'. ${ }^{47}$ The press release further claimed that 'the Delhi government has also failed to pay NGOs money for the salaries of their caretakers since March 2011'. As testified by the High Court of Delhi's interim orders, the NGOs were not 
held responsible for the shelters' poor conditions. The Court instead directed the Delhi government to release the funds to the NGOs. ${ }^{48}$ In brief, media attention on homeless issues over the last four years is certainly not sufficient to support the movement; the media need to report responsibly with prior proper investigation. ${ }^{49}$ More generally, social movements never entirely control the media (Neveu 1999) and journalists cannot be systematically considered as benevolent partners.

\section{Divergences in the coalition}

51 Some competition and divergences of views emerged among the CSOs working with the homeless. In particular, the controversy over the UID project that arose among the organisations participating in the Mission Convergence scheme, touches a deeper demarcating line, dividing CSOs and activists: it points to the limits of the publiccommunity partnership. For some, comfortable in this invited space, the time has come to cooperate with the government, in order to alert the latter to the problems on the ground and to better understand the grassroots' perspective. Others fear that close association with the government will deprive CSOs of their autonomy and position to oppose government policy and decisions, even when these fail to serve the interests of the homeless. In other words, there is a risk of the distance between CSOs and the state disappearing in public-community partnership. Co-option of voluntary organisations in implementing government schemes could be a way of silencing dissenting voices (see also Tawa Lama-Rewal 2011). Those activists, critical of the benefits of participation in invited spaces, put forward the benefits of confrontational interactions with the state. Eventually, the lack of convergence of the coalition's actors on important issues is likely to be detrimental to the future outcomes of the broader movement.

\section{Conclusion}

52 The review of the public schemes for the homeless in Delhi and the scrutiny of a mobilisation campaign triggered by a tragic case of eviction highlight the CSOs' different spaces of participation on homelessness-related issues. According to the distinction proposed by Miraftab (2004) between 'invited' and 'invented' spaces of citizenship, spaces provided by the government, such as the Joint Apex Advisory Committee for the Homeless and the public-community partnership initiated under Mission Convergence, are invited spaces, whereas press conferences, public hearings and rallies organized by the CSOs qualify as invented spaces. In the mobilisation campaign examined here, a third and very significant type of space seems to have emerged-one I call a 'pleading space', namely the courtrooms where the CSOs advocate their cause in a confrontational manner vis-à-vis state institutions but within the codified structure of the judicial system.

The scrutiny of this specific campaign points to more general trends. The provision by the government of invited spaces for participation illustrates 'a trend characteristic of contemporary urban governance in India' (Tawa Lama-Rewal 2011: 18). At the same time, diverging positions among CSOs and activists regarding the merits of participation versus those of confrontation with the state reflect recurrent debates that have taken place on a broader scale in Indian civil society (Jenkins 2010). Furthermore, the courts' decisive role exemplifies the increasing intervention of the judiciary in urban governance in India, 
though, unlike in this case, not necessarily in the interests of the urban poor (Dupont \& Ramanathan 2008).

Several challenges question the sustainability of the campaign outcomes. Despite the CSOs' active engagement and the courts' continuing intervention, the achievements of the homeless cause are still fragile, unconsolidated, and subject to setback or even regression. This fragility results mainly from the ambiguity of the state position towards the homeless-it being understood that the state is not a monolithic entity but embodied by multiple institutions. The homeless are considered vulnerable people deserving protection; at times they may be recognised as citizens with some entitlements and rights. On the other hand, they are marginalized and neglected, or treated as public offenders and encroachers on the public space. The 'fluidity of the situation' (also observed for Mumbai pavement dwellers-Mohapatra 2003) requires the constant vigilance of the CSOs working for and with the homeless and an unrelenting struggle to defend their rights to a proper place in the city.

\section{BIBLIOGRAPHY}

AAA (Aashray Adhikar Abhiyan) (2001) The Capital's Homeless. A Preliminary Study, Delhi: Aashray Adhikar Abhivan Publication.

Bautès, Nicolas; Dupont, Véronique; Landy, Frédéric (2013) ‘Acting from the Slums: Questioning Social Movement and Resistance', in Frédéric Landy \& Marie-Caroline Saglio-Yatzimirsky (eds.), Megacity Slums. Social Exclusion, Urban Space and Policies in Brazil and India, London: Imperial College Press, pp. 363-407.

Baviskar, Amita (2003) 'Between Violence and Desire: Space, Power, and Identity in the Making of Metropolitan Delhi', International Social Science Journal, 55(175), pp. 89-98.

Benit-Gbaffou, Claire (2008) 'In the Shadow of 2010-A Fast-Tracked Local Democracy, or How to Get Rid of the Poor in Greater Ellis Park Development Project, Johannesburg', in Udesh Pillay, Richard Tomlinson \& Orli Bass (eds.), Development and Dreams: Urban Development Implications of the 2010 Soccer World Cup, Pretoria: HSRC Press, pp. 200-22.

Broudehoux, Anne-Marie (2007) 'Spectacular Beijing: the Conspicuous Construction of an Olympic Metropolis', Journal of Urban Affairs, 29(4), pp. 383-99.

Bhan, Gautam; Shivanand, Swathi (2013) '(Un)Settling the City. Analysing Displacement in Delhi from 1990 to 2007', Economic and Political Weekly, 48(13), pp. 54-61.

Bharat Sevak Samaj (1964) A Roof Over the Head, Delhi: Delhi School of Social Work, University of Delhi.

Cornwall, Andrea (2002) Making Spaces, Changing Places: Situating Participation in Development, IDS Working Paper 170, Brighton: Institute of Development Studies.

Cornwall, Andrea; Coelho, Vera Schattan P. (2007) 'Spaces for Change? The Politics of Participation in New Democratic Arenas’, in Andrea Cornwall \& Vera Schattan P. Coelho (eds.), 
Spaces for Change? The Politics of Citizen Participation in New Democratic Arenas, London: Zed Books, pp. 1-29.

Davis, Mike (2006) Planet of Slums, New York: Verso.

DDA (Delhi Development Authority) (2007) Master Plan for Delhi 2021. [As Notified on $7^{\text {th }}$ February, 2007]. Vide S.O. $\mathrm{N}^{\circ} 141$ published in Gazette of India Extraordinary [Part II-Section 3 Sub-Section (ii)].

DeVerteuil, Geoffrey (2006) ‘The Local State and Homeless Shelters: Beyond Revanchism?', Cities, 23(2), pp.109-120

DeVerteuil, Geoffrey; Marr, Matthew; Snow, David (2009) 'Any Space Left? Homeless resistance by place-type in Los Angeles county’, Urban Geography, 30(6), pp. 633-651.

DeVerteuil, Geoffrey; May, Jon; Von Mahs, Jürgen (2009) 'Complexity not Collapse: Recasting the Geographies of Homelessness in a 'Punitive' Age', Progress in Human Geography, published on line 21 May 2009, pp. 1-21.

Dewan Verma, Geeta (2002) Slumming India. A Chronicle of Slums and their Saviours, Delhi: Penguin Books India.

Dupont, Véronique (2000) ‘Mobility Patterns and Economic Strategies of Houseless People in Old Delhi', in Véronique Dupont, Emma Tarlo \& Denis Vidal (eds.) Delhi. Urban Space and Human Destinies, Delhi: Manohar \& Centre de Sciences Humaines, pp. 99-124.

Dupont, Véronique (2008) ‘Slum Demolition in Delhi since the 1990s. An Appraisal', Economic and Political Weekly, 43(28), pp. 79-87.

Dupont, Véronique (2010) ‘Création de nomades urbains et appauvrissement. Impact des politiques d'éradication des camps de squatters à Delhi', Revue Tiers Monde, 201, pp. 25-45.

Dupont Véronique (2011) ‘The Dream of Delhi as a Global City’, International Journal of Urban and Regional Research, 35(3), pp. 533-54.

Dupont, Véronique; Ramanathan, Usha (2007) ‘Du traitement des slums à Delhi. Politiques de « nettoyage » et d'embellissement', in Véronique Dupont \& Djallal Gérard Heuzé (eds.), La ville en Asie du Sud: Analyse et mise en perspective, Purushartha 26, Paris: EHESS, pp. 91-131.

Dupont, Véronique ; Ramanathan, Usha (2008) 'The Courts and the Squatter Settlements in Delhi. Or the Intervention of the Judiciary in Urban "Governance", in I.S.A. Baud and Joop de Wit (eds.), New Forms of Urban Governance in India. Shifts, Models, Networks, and Contestations, New Delhi: Sage, pp. 312-343.

Fernandes, Leela (2004) 'The politics of forgetting; class politics, state power and the restructuring of urban space in India', Urban Studies 41(12), pp. 2415-2430.

Ghertner, Asher (2010) 'Calculating without numbers: aesthetic governmentality in Delhi's slums', Economy and Society, 39(2), pp. 185-217.

GNCTD-UNDP (2011) Homeless survey 2010 (Draft). Project Management Unit, GNCTD-UNPD Project, Delhi: Government of National Capital Territory of Delhi.

Hazards Centre (2010) Heritage Games. Cleaning up the debris, Delhi: Hazards Centre Publication.

HLRN-HIC (2010) The 2010 Commonwealth Games: Whose wealth? whose commons? New Delhi: Housing and Land Rights Network, Habitat International Coalition - South Asia Regional Programme. 
HLRN-HIC (2011) Planned Dispossession: Forced Evictions and the 2010 Commonwealth Games, Fact Finding Report Mission 14, New Delhi: Housing and Land Rights Network, Habitat International Coalition - South Asia Regional Programme.

IGSSS (2012) The Unsung City Makers. A study of the homeless Residents of Delhi, New Delhi: Indo-Global Social Service Society.

Jenkins, Rob (2010) 'NGOs and India politics', in Niraja Gopal Jayal \& Pratap Bhanu Mehta, The Oxford Companion to Politics in India, Oxford: Oxford University Press, pp. 409-426.

Joshi, V. (2011), Census of India 2011, Provisional Population Totals, NCT of Delhi, Paper 1 of 2011, Delhi: Directorate of Census Operation.

Khosla, Renu, Jha G. (2005) Economics of resettling low-income settlements (Slums) in urban areas: a case for on-site upgrading, Draft Final Report, Delhi: Centre for Urban and Regional Excellence, South Asia Network of Economic Research Institute.

Kumar, Ravi (2008), 'Globalization and changing patterns of social mobilization in urban India', Social Movement Studies, 7(1), pp. 77-96.

MacLeod, Gordon (2002) 'From urban entrepreneurialism to a "revanchist" city? On spatial injustices of Glasgow's renaissance', Antipode, 34, pp. 603-624

Maitra, Shipra; Metha, Balwant Singh (2007) Shelterless persons in Delhi. Challenging inclusive growth policies, New Delhi: Institute for Human Development (sponsored by Department of Social Welfare, NCT of Delhi).

Mander, Harsh (2009) 'Living rough, surviving city streets. A study of the homeless populations in Delhi, Chennai, Patna and Madurai', in Urban Poverty Report, 2009, Ministry of Housing and Urban Poverty Alleviation and United Nations Development Programme, New Delhi: Oxford University Press, pp. 287-308.

Menon-Sen, Kalyani; Bhan, Gautam (2008) Swept off the Map. Surviving Eviction Resettlement in Delhi, Delhi: Yodapress.

Miraftab, Faranak (2004) 'Invited and invented spaces of participation: neoliberal citizenship and feminists' expanded notion of politics', Wagadu, 1(Spring), pp. 1-7.

Mohapatra, Bishnu N. (2003) 'A view from the subalterns. The pavement dwellers of Mumbai', in Rajsh Tandon \& Ranjita Mohanti (eds.), Does Civil Society Matter? Governance in Contemporary India, New Delhi: Sage Publication, pp. 285-314.

Neveu, Erik (1999) ‘Médias, mouvements sociaux, espaces publics', Réseaux, 17(98), pp. 17-85.

Ramanathan, Usha (2008) 'Ostensible Poverty, Beggary and the Law', Economic and Political Weekly, 43(44), pp. 33-44.

Ramanathan, Usha (2010) ‘A Unique Identity Bill', Economic and Political Weekly, 45(30), pp. 10-14.

Rao, Ursula (2013) 'Biometric Marginality: UID and the Shaping of Homeless Identities in the City’, Economic and Political Weekly, 48(13), pp. 71-77.

SCCO (2011) Delhi Homeless Shelter Plan, National Resource Team for the Homeless, New Delhi: Supreme Court Commissioner's Office.

Smith, Neil (1996) The New Urban Frontier: Gentrification and the Revanchist City, London: Routledge. 
Tandon, S.L. (2007) Report on the Survey of the Delhi Beggars in Delhi, Delhi: Department of Social Work, University of Delhi.

Tawa Lama-Rewal, Stéphanie (2011a) ‘Urban Governance and Health are Provision in Delhi', Environment \& Urbanization, 23(2), pp. 1-19.

Tawa Lama-Rewal, Stéphanie (2011b) ‘Urban Governance: How Democratic?', in Marie-Hélène Zérah, Véronique Dupont \& Stéphanie Tawa Lama-Rewal (eds.), Urban Policies and the Right to the City in India. Rights, Responsibilities and Citizenship, New Delhi: UNESCO \& Centre de Sciences Humaines, pp. 21-30.

The Times of India (New Delhi). 2009. 'Out in the Cold on Christmas Eve', 25 December.

The Hindu. 2012. ‘6,000 Homeless Persons Get Voter-ID Cards in Delhi’, 21 November.

Tingal, Dhananjay; Pandey, Vijay Kumar (2008) The Known Unknown: A Study of the Homeless People in Delhi, New Delhi: Indo-Global Social Service Society.

Zérah, Marie-Hélène; Tawa Lama-Rewal Stéphanie; Dupont, Véronique; Chaudhuri, Basudeb (2011) 'Right to the City and Urban Citizenship in the Indian Context', in Marie-Hélène Zérah, Véronique Dupont \& Stéphanie Tawa Lama-Rewal (eds.), Urban Policies and the Right to the City in India. Rights, Responsibilities and Citizenship, New Delhi: UNESCO \& Centre de Sciences Humaines, pp. 1-11.

\section{NOTES}

1. The research presented in this paper is part of a larger on-going international programme entitled 'Urban Chances-City growth and the sustainability challenge' (www.chance2sustain.eu) funded by the European Framework Programme (FP7) from 2010 to 2014. I also received financial support from IRD (Institute of Research for Development), as well as logistic support from the Centre de Sciences Humaines during my research stays in Delhi. Investigations for the informal settlement's case study were conducted with the assistance of Dhananjay Tingal and M.M. Shankare Gowda; these would not have been possible without the cooperation of the Beghar Majdoor Sangarsh Samiti and its director, Mansoor Khan. I am also thankful to all the persons interviewed for giving their time and sharing information. A first version of this paper was presented at the European Conference on South Asian Studies, Lisbon, 25-28 July 2012. Valuable comments from Stéphanie Tawa-Lama Rewal, Radhika Govinda and Diya Mehra helped me in revising this draft. Finally, I am thankful to the anonymous referees of the Journal for their pertinent suggestions. All other disclaimers apply.

2. 'Out in the cold on Christmas eve'. The Times of India .New Delhi, 25 December 2009.

3. AAA website: http://homelesspeople.in (accessed on 10/07/2012).

4. Jhuggi-jhompri is the local term used to designate squatter settlements. In this paper, I use the term 'slum' to refer to this type of settlement.

5. Source: Slum and Jhuggi-Jhompri Department, MCD. This Department was in charge of the implementation of the squatter settlements relocation scheme, as part of the MCD till 2010, and then transferred to the DUSIB, under the Government of the National Capital Territory of Delhi (henceforth Government of Delhi).

6. Source: Slum and Jhuggi-Jhompri Department, MCD.

7. Amod K. Kanth, 'Housing for the Urban Poor: a Case for the Homeless in Delhi' (n.d.) [the author was a member of the Joint Apex Advisory Committee when he was the Joint Commissioner of Police, Delhi]. URL: http://www.prayaschildren.org/publications.htm (accessed on 13/07/2012). 
8. Sajha Manch is a forum of mass organisations, NGOs and individuals campaigning on housing issues for the urban poor.

9. Source: website of Mission Convergence: http://www.missionconvergence.org/ (accessed on 5/03/2013).

10. Source: Head of the homeless project at St Stephen Hospital, interview by author, Delhi, 16 March 2011.

11. See: UIDAI (2012) Social Inclusion and Aadhaar: Introduction \& Concept Paper. Unique Identification Authority of India, 30 April 2012. URL: http://uidai.gov.in/images/ concept_paper_social_inclusion.pdf (accessed on 12/07/2012)

12. To summarise, the criticisms 'focus on three aspects: the reliability, security and misuse of data' (Tawa Lama-Rewal 2011b: 27). See also Ramanathan (2010) and Rao (2013).

13. I analysed elsewhere this process consisting in 'cleansing the city of slums and other alleged undesirable elements' such as peddlers, beggars, vagrants and homeless people (Dupont 2011: 550), as well as its historical context (Dupont \& Ramanathan 2007); see also Fernandes (2004: 2416) for a discussion of similar processes in Mumbai.

14. High Court of Delhi, Writ Petition (Civil) No 29 of 2010, Court on its Own Motion versus Government of National Capital Territory of Delhi [Govt. of NCT Delhi] and others.

15. High Court of Delhi, WP(C) No 29 of 2010, Order dated 13 January 2010.

16. Supreme Court of India, section PIL, Writ Petition (Civil) No 196 of 2001, People's Union for Civil Liberties versus Union of India \& others, order dated 20 January 2010.

17. Supreme Court of India, section PIL, WP (C) No 196 of 2001, People's Union for Civil Liberties versus Union of India \& others.

18. Supreme Court of India, WP (C) (Civil) No 196 of 2001, Order dated 5 May 2010.

19. 'National Programme for Shelters and Other Services for the Urban Homeless'. Recommendations of National Advisory Council \& Explanatory Note. National Advisory Council (Government of India, Prime Minister's office), Working Group on Urban Poverty (Convener: Shri Harsh Mander), Communication to the Government on 14 March 2012. URL: http://nac.nic.in/ up.htm \& http://nac.nic.in/communication.htm (last accessed on 12/07/2012)

20. See URL: http://archiperspecta.com/files/nasa/HUDCO2012Brief24/HUDCO-2012-final.pdf (retrieved on 28-05-2013). HUDCO is a public sector undertaking under the Union Ministry of Housing and Urban Poverty Alleviation.

21. See: 'Caravan for Homeless', Civil Society News, February 2011, and the report on the IGSSS website, the NGO that organised this campaign: http://www.igsss.org/newsevents/national-citymakers-caravan (accessed on 20/11/2013).

22. See the IGSSS Newsletter (vol. 11, issue 6, Nov-Dec 2010, p. 2), published by the NGO that promoted the designation 'City Makers': URL: igsss.org/wp-content/uploads/2013/07/6.IGSSSNewsletter-nov-dec.pdf (retrieved on 20/11/2013).

23. I borrow this idea and phrasing from Vyjayanti Rao (talk on 'Cities and Citizenships-New Political Subjectivities', Paris, CEIAS, 12/06/2012).

24. For instance, 'Making Delhi a caring city: Review and way forward', National Consultation organised by IGSSS in Delhi, 13/03/2012. See: http://www.igsss.org/newsevents/making-delhi-acaring-city-review-way-forward (accessed on 20/11/2013).

25. '6,000 homeless persons get Voter-ID cards in Delhi', The Hindu, 21 November 2012.

26. For example, Indo-Global Social Service Society (IGSSS), an NGO whose initiatives for the homeless are highlighted above.

27. For instance, the Land Rights Network, part of Habitat International Coalition.

28. Recently changed to 'Begharon Ke Sath', this new semantic shift from 'for the homeless' to 'with the homeless' is again significant as it underlines homeless people's agency. 
29. Source: Letter from Miloon Kothari, former United Nations Special Rapporteur on Adequate Housing, to Honourable Justice A.P. Shah, Chief Justice, High Court of Delhi, dated 10 January 2010 .

30. Source: Letter from Dr N.C. Saxena, Commissioner and Harsh Mander, Special Commissioners of the Supreme Court in the case People's Union for Civil Liberties versus Union of India \& others Writ Petition (Civil) No 196. Of 2001, to The Honourable Supreme Court of India, dated 13 January 2010, Subject: Relief for homeless people living on the streets of Delhi, in the context of cold wave related deaths.

31. Source: Ibid.

32. Supreme Court of India, WP (C) No 196 of 2001, order dated 20 January 2010.

33. Supreme Court of India, WP (C) No 196 of 2001, order dated 5 May 2010.

34. Letter from Miloon Kothari; SAM-BKL, 'Recommendations towards protecting the human rights of Delhi's homeless', Submitted to the High Court of Delhi in February 2010. In addition, the preliminary report of the 2008 survey conducted by IGSSS (Tingal \& Pandey 2008) was a supporting document submitted to the Supreme Court in February 2010 in the Right to Food case (Supreme Court of India WP(C) No 196 of 2001).

35. See the interim orders of the High Court of Delhi on this case available at: http:// delhihighcourt.nic.in/dhc_case_status_oj_list.asp?pno=528490 (accessed on 29/05/2013).

36. Source: CSO representative participating in the committee, interviews by author, Delhi, 19 December 2012 and 4 April 2013.

37. SAM-BKL, Press release, 05 March 2011.

38. SAM-BKL, Press conference in New Delhi \& Press release, 05 March 2012.

39. Recommendation of the Master Plan Management Action Committee, approved by a DDA meeting on 15 May 2012.

40. NGO activist, interview by author, Delhi, 4 December 2012; 'There will be one night shelter for one lakh population', Dainik Jagarn, 7 November 2012.

41. See: http://delhihighcourt.nic.in/dhc_case_status_oj_list.asp?pno=528490 (accessed on 29/05/2013).

42. Delhi has a dedicated beggars' court and 12 beggars' homes, with a capacity for housing 3,600 inmates.

43. 'India must address forced eviction and other human right abuses in Delhi during the Commonwealth Games', Amnesty International Statement, 4/10/2010 (Al Index: ASA 20/029/2010), London.

44. Supreme Court of India, Suo Moto Writ Petition (CRL) No 122 of 2011, in relation to Ramlila Maidan Incident dated 4/5.06.2011, vs. Home Secretary, Union of India \& others. Judgement dated 23 February 2012.

45. 'Making Delhi a caring city: Review and way forward' (Ibid). Usha Ramanathan highlighted this judgement during the consultation.

46. For instance: 'HC [High Court] raps NGOs for Poor Upkeep of Night Shelters for Homeless', Times of India, 21 July 2011.

47. 'Coalition for the homeless alarmed over inaccurate and biased media report', SAM-BKL, Press Release, 21 July 2011.

48. See High Court of Delhi, WP(C) No 29 of 2010, Court on its Own Motion versus Govt. of NCT Delhi \& others, Order dated 20 July 2011.

49. 'Shari Adhikar Manch: Begharon Ke Liye urgently calls upon the media to report responsibly', SAM-BKL, Press Release, 21 July 2011. 


\section{ABSTRACTS}

The socio-spatial restructuring of Delhi was accompanied by large-scale slum demolitions that increased homelessness. This paper focuses on the people made homeless, and their struggle to assert their place in the city. First, it expounds the context of homelessness in Delhi and analyses the mechanisms behind its aggravation. Then, it examines a decisive moment in this struggle: a mobilisation campaign for the homeless' right to shelter, triggered by a tragic eviction during the preparations for the 2010 Commonwealth Games. This research shows that the campaign's success is due to the combination of long-term structural work at the grassroots level and the timely reaction of various connected actors in different spheres (civil society, media, justice) and institutional levels, and how the campaign for the homeless faces several challenges in sustaining its outcomes.

\section{INDEX}

Keywords: homeless, mobilisation campaign, right to shelter, Delhi, spaces of citizenship

\section{AUTHOR}

\section{VÉRONIQUE DUPONT}

Research fellow, Institut de Recherche pour le Développement, Paris 